\title{
Bible Learning with Board Game for Children
}

\author{
Budi Susanto $^{1}$, Wahju Satria Wibowo ${ }^{2}$, Centaury Harjani $^{3}$, Koniherawati $^{4}$ \\ ${ }^{1}$ Faculty of Information Technology, Duta Wacana Christian University, Indonesia \\ ${ }^{2}$ Faculty of Theology, Duta Wacana Christian University, Indonesia \\ ${ }^{3,4}$ Faculty of Architecture and Design, Duta Wacana Christian University, Indonesia \\ Corresponding Author's Email : budsus@ti.ukdw.ac.id
}

\begin{abstract}
Bible literacy, specifically biblical stories, has been widely told and taught to children both at school and at church through Sunday school from an early age. However, there is no guarantee that these children will have an interest in biblical stories, especially when they reach adolescence. There is a need for more creative learning methods for children to learn biblical stories. It has been known that by adopting fun learning, children will be able to absorb more knowledge hence they are able to learn more actively. Children who are actively learning by initiative will be able to develop quicker. For that purpose, teaching tools are needed to support children. One approach is learning by playing. In this research, we propose the development of a board game to support the need of Bible literacy. The theme used on this board game is the story of Moses in the book of Exodus. We intentionally use colorful and attractive cartoon drawings to attract children. The board game includes interactive forms where players can quiz one another when they reach a certain position on the board. We use several assessment components to build competition between players. The aim of this board game is to create a more engaging learning experience of biblical stories for children, hence increasing their interest in the Bible from an early age.
\end{abstract}

Keywords: fun learning, board game, creative education, Bible

\section{INTRODUCTION}

The digital age where children are familiar with gadgets makes children prefer digital games. The negative impact on children who are addicted is the tendency to play individually and have no interest other than the games they play. Another impact is that children lack a focus on learning, such as reading, including reading the Bible.

Children who have been introduced to Sunday school since childhood do not guarantee that children have an interest in Bible stories, especially children who begin to enter adolescence. Games that support children's interest in the Bible are rarely found on the market. Very few Bible literacy games for children. One opportunity to introduce the Bible to children is to enter the world of children's play. We believe that developing board games based on Bible stories can help improve literacy about the Bible to children, youth, youth, or even parents. This increase in 
literacy is significant to strengthen fundamental theology. The game is believed to help to achieve these goals. Board games with contemporary designs can be used to introduce Bible stories as well as to bridge children to play with their peers. The design and content of the game certainly must be considered.

Spiritual education by using board games is believed to help Christian children to understand the Bible story and then be used as the basis of their lives. Thus in this study, the focus will be on how to design a board game that can foster interest in Bible literacy in children and bridge children to social interaction. How successful the board game design is based on the story of the Bible that was developed can achieve its objectives as a means of learning spirituality for Christian children with a playtesting approach.

This research activity will emphasize several limiting conditions. Board games are designed based on a Bible story by selecting one of the stories in Genesis and Exodus. Board games are designed for players who are at least ten years old who are believed to have the ability to think logically to solve problems concretely (based on Piaget's cognitive development theory (Cherry, 2018)).

Based on this background, this study aims to produce a prototype board game for children as a medium for learning Bible literacy; and produce games as tools to build children's social interactions.

\section{LITERATURE REVIEW}

If it follows the definition written by Freeman (2012), a board game is a game made with cards and glue that requires imagination and literal interaction, not virtual, to be played. Board games have been played for centuries, which are found separately in various cultures. For example, a game called 58 Holes is claimed to be a 4000-year-old game found at the Azerbaijan Stone Reservoir (More, 2018). There are other games found and claimed to be hundreds or even thousands of years old, including Viking Chess, Lewis Chessman, Norwegian Knight, and others, as reported by Metcalfe (2018). Of the many historical board games available, Walker (2014) has chosen 12 historical board games based on time criteria, clarity of rules, and spread across several regions. The selected game can be used as a foundation for ideas and further development of board games.

Nowadays, board games have developed with more mixed media. If we view the data published on the BoardGameGeek.com ${ }^{1}$ site, there are approximately 1047 board games recorded. There is even a group of researchers and learning related to board games, namely The International Board Game Association ${ }^{2}$. Research and learning about games is called game study or ludology. Again, if we look at the grouping of board games published by BoardGameGeek.com, there are approximately 84 categories. This grouping is based on the development of the types of games, rules, and devices used. However, if we look at the categories that still exist today, board games can be seen as card games, using dice, education, memory, Puzzles, Numbers, and Abstract Strategy (for example, chess).

\footnotetext{
${ }^{1}$ https://www.boardgamegeek.com/browse/boardgame

${ }^{2}$ https://www.parlettgames.uk/games/
} 
With so many variations to date, board games have provided many benefits to players. Siegler \& Ramani (2009) published that with linear board games help children to name numbers, count and remember, understand sequences, understand numbers, understand approximate numbers, and learn to answer arithmetic problems. In line with this, Harris (2009) also stated that introducing board games into the classroom can be more effective when they are aligned with curriculum standards.

In the construction of board games, it is necessary to consider the target players who will play it. The target players targeted in this study are between the ages of 7-12 years. According to Piaget's theory of cognitive development, Cherry (2018) summarizes and explains it easier to understand. Piaget's theory says that children play an active role in the learning process, acting like little scientists when they conduct experiments, make observations, and learn about the world. Piaget divides cognitive development into several steps, namely: Sensorimotor (born to 2 years), Preoperational (ages 2 to 7 years), concrete operations (ages 7 to 11), and formal operations (ages 12 and above). Specifically, at the concrete operational stage, Cherry (2018) explains that children aged 7-11 years become much more logical and sophisticated in their thinking. Two main characteristics at this stage, children are good enough in the use of inductive logic (inductive reasoning). Another important characteristic is the understanding of reversibility or the realization that actions can be reversed.

In designing and making a board game, the methodology used in general uses the principles of game development in general. Refer to the methodology suggested by Barbosa et al. (2014), in a serious game, the pleasure factor must be maintained in the first place. Therefore, to provide a vibrant and attractive environment that presents educational goals, the best practice of pedagogical psychology is needed. Real learning should be in the game. This learning process will share many characteristics with learning pedagogy based on problems. Players must solve problems to progress through the game, and they can only solve the problems provided by gathering the experience and tools needed at the lower levels of the game. Figure 1 shows the methodology diagram related to the learning mechanism at each level of the game.

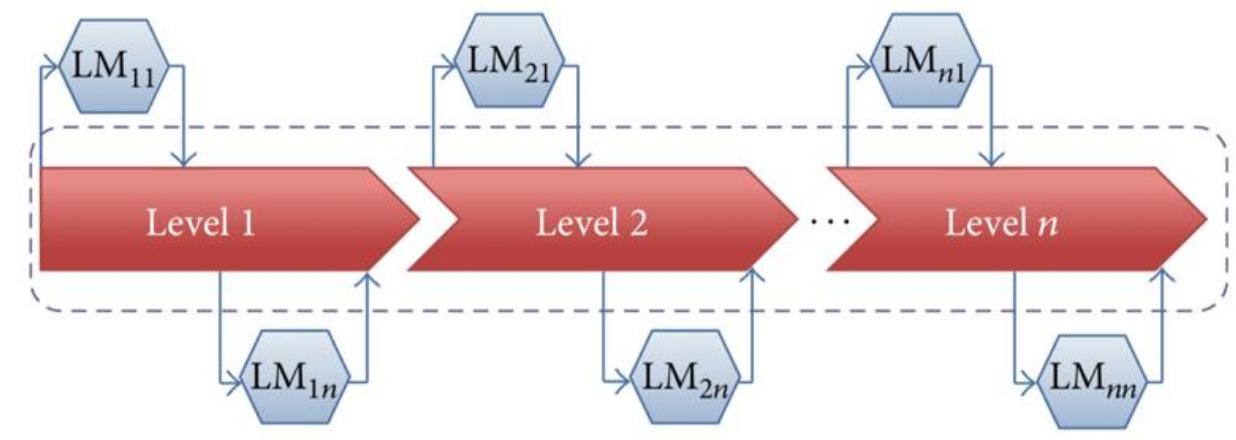

Figure 1. Methodology of Learning Mechanisms in Games (Barbosa, Pereira, Dias, \& Silva, 2014) 
Specifically for the development of board games, Silverman's (2013) opinion on the stages of developing board games can be followed. The methodology described by Silverman consists of stages: 1) start by gathering ideas; 2) write down all ideas by emphasizing what the game is going to be built about and how to play it (and some other questions); 3) game content development; 4) design and build prototype games; 4) game testing and evaluation (with the help of several questions); and 5) complete and release.

Regarding the game engineering based on the story of the Bible, because of the specificity of the players for whom it was intended, perhaps the opinions of Mader, Levieux, \& Natkin (2016), who designed gameplay for therapeutic games can be adopted. The model offered is called the P / G / T model, which is a playerpatient model, game model, and therapy model. Each model contains a list of essential elements that describe aspects related to the therapeutic game. Understanding related elements in the development of a game, including board games, becomes essential to help determine the type and purpose of the game to be developed.

From a game produced, before entering the production stage, the game prototype must be tested first. There are nine types of testing of games (testbytes.net, 2017), including combinatorial testing, clean room testing, functionality testing, compatibility testing, tree testing, regression testing, ad hoc testing, load testing, and play testing. Of the nine testing techniques, one of the techniques considered suitable for testing a board game is the play testing technique. The play testing technique will emphasize several steps (John, n.d.): 1) recruit players who are the target of the trial; 2) Test before the game is tested; 3) release the pressure so the testers play like playing everyday; 4) collect questions and game time; and 5) analysis of test results.

\section{METHODOLOGY}

To be able to produce a Board Game product that is based on stories written in the Bible, in principle, it will follow the game development methodology that was revealed by Silverman (2013), Heaton (2006), Steve Jackson Games (n.d.), and Rouse (2005, pp. 449-474). Table 1 is the steps that will be carried out in this study, along with the method and its output. 


\begin{tabular}{|c|c|c|c|c|}
\hline No. & Steps & Method & Indicator & Output \\
\hline 1. & $\begin{array}{l}\text { Collecting the ideas for } \\
\text { the selection of Bible } \\
\text { stories that will be the } \\
\text { basis }\end{array}$ & $\begin{array}{l}\text { Focus Group } \\
\text { Discussion }\end{array}$ & $\begin{array}{l}\text { Availability of } \\
\text { game solution } \\
\text { idea documents }\end{array}$ & $\begin{array}{l}\text { Bible stories that } \\
\text { are } \\
\text { supplemented by } \\
\text { a picture of } \\
\text { complexity in } \\
\text { the game }\end{array}$ \\
\hline 2. & Defining game scenarios & $\begin{array}{l}\text { Focus Group } \\
\text { Discussion }\end{array}$ & $\begin{array}{l}\text { The } \\
\text { availability of } \\
\text { game sketch } \\
\text { designs }\end{array}$ & $\begin{array}{l}\text { Game scenarios } \\
\text { can be translated } \\
\text { in sketches }\end{array}$ \\
\hline 3. & Sketching the game & $\begin{array}{l}\text { Linear } \\
\text { Drawing } \\
\text { Techniques }\end{array}$ & $\begin{array}{l}\text { Sketch } \\
\text { available }\end{array}$ & $\begin{array}{l}\text { Game Sketch is } \\
\text { ready to print }\end{array}$ \\
\hline 4. & $\begin{array}{l}\text { Making Game } \\
\text { Prototypes }\end{array}$ & $\begin{array}{l}\text { Game Play } \\
\text { Design } \\
\text { Techniques }\end{array}$ & $\begin{array}{l}\text { The creation of } \\
\text { the Board } \\
\text { Game } \\
\text { according to } \\
\text { the scenario } \\
\text { and design }\end{array}$ & $\begin{array}{l}\text { Board Game } \\
\text { Prototype }\end{array}$ \\
\hline 5. & Testing the prototype & $\begin{array}{l}\text { Playtesting } \\
\text { technique }\end{array}$ & $\begin{array}{l}\text { Obtained } \\
\text { evaluation } \\
\text { results }\end{array}$ & $\begin{array}{l}\text { Evaluation of } \\
\text { Board Game } \\
\text { Implementation }\end{array}$ \\
\hline 6. & $\begin{array}{l}\text { Improvements to the } \\
\text { Final Prototype }\end{array}$ & $\begin{array}{l}\text { Game Play } \\
\text { Design } \\
\text { Techniques }\end{array}$ & Board Game & $\begin{array}{l}\text { Board Game } \\
\text { final version }\end{array}$ \\
\hline 7. & Final Prototype Testing & $\begin{array}{l}\text { Playtesting } \\
\text { technique }\end{array}$ & $\begin{array}{l}\text { Obtained } \\
\text { evaluation } \\
\text { results }\end{array}$ & $\begin{array}{l}\text { Evaluation of } \\
\text { Board Game } \\
\text { Implementation }\end{array}$ \\
\hline
\end{tabular}

Table 1. Research Methodology

\section{RESULTS AND DISCUSSION}

The title of the board game is the Calling of Moses that is designed based on the theme of the Israelites journey led by Moses to break out of slavery in Egypt. Moses, guided and protected by God, led the Israelites to begin their long journey to the promised land. All the thrilling stories about this journey are recorded in the Bible, specifically in the book of Exodus.

The episode when Moses got two stone tablets at Mount Sinai was the end of the journey of The Calling of Moses. Players will be guided learning about how God, through the mediation of Moses, struggling with Pharaoh in order to take free the Israelites from Egypt. Learning about the ten plagues is also included in this game. In each journey, the players will face several obstacles in the form of 
questions. Each question can contain Hint (help), and there is also a reward available. The dice are used as a determinant of how far a player can continue on his journey. The player determines the direction of travel by following the rules. In the end, the player who can collect the most rewards, has all the prerequisites, occupies as much territory as possible, and who has reached the finish line, that will be the winner.

This game can be played by 2 to 4 people. The age category that is designed to be able to play is a minimum of 10 years. The players are not required to know the complete and detailed story of Moses, because with this game, players can learn a lot about Moses' journey.

Some of the components used in the game The Calling of Moses include:

1. Board. This board (Figure 2) is divided into two parts based on the story of Moses: 1) starting from Moses meeting Pharaoh until bringing the Israelites out of the land of Egypt; and 2) after Moses and the Israelites walked through the Red Sea (Teberau sea) and went to Mount Sinai.

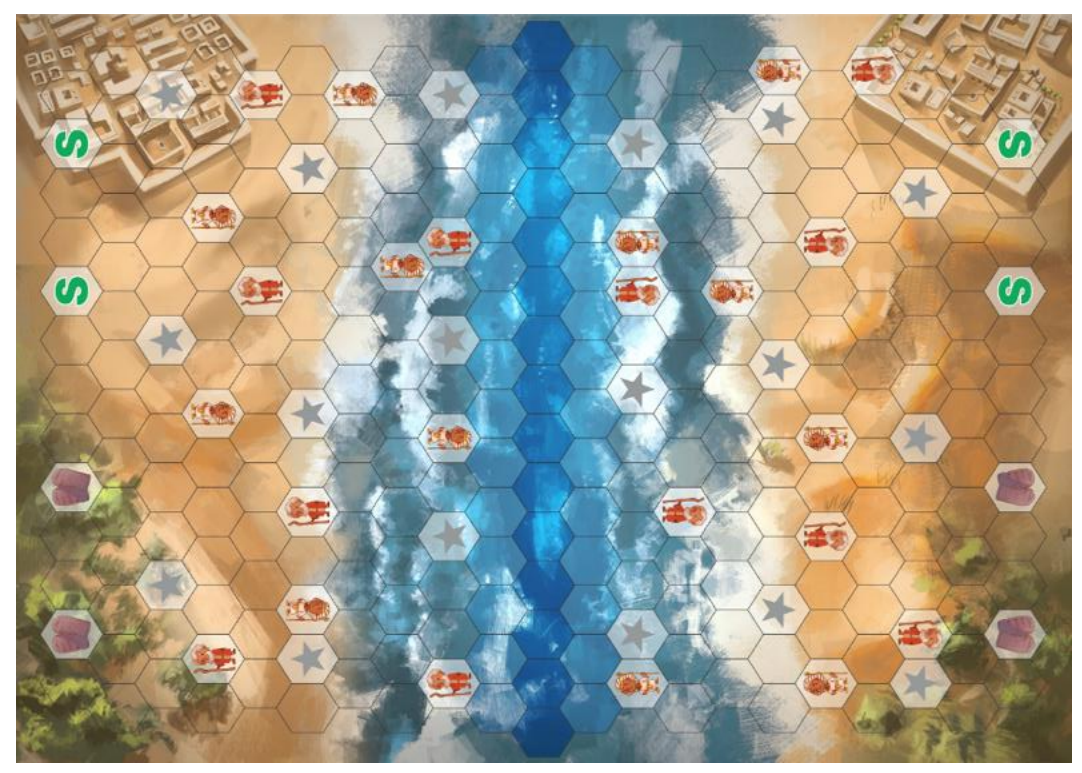

Figure 2. Board of Game

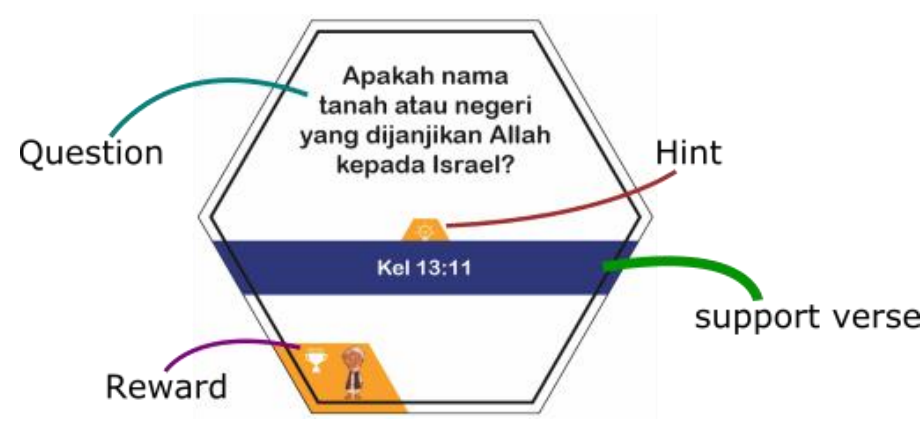

Figure 3. The question card elements. 
2. Each player will play as Moses (presented as a pawn) that showed a specific cloak color of Moses. There are four colors: green, purple, yellow, and blue.

3. Dice. The dice used is designed like a dice with six sides. But what is used in this game is only numbers $1-4$, while on the sides of the dice the numbers 5 and 6 are eliminated.

4. The question cards. The question cards are divided into two groups, namely questions in the category of Pharaoh that were used before the Israelites met the Red Sea. The second group is the category of Moses, which was used after the Israelites crossed the Red Sea. In each question card, there are several sections, as shown in Figure 3.

5. Plague cards. When the question card has a plague picture, the player who opens the question for his opponent will get the Plague card with the picture according to the question card. The ten plagues used are shown in Figure 4.

6. Star cards. Each player who places his pawns in the Star-marked box on the game board, and in the Star box that has not been mastered by other players, then the player has the right to place a Star Sign Card in color according to the color of Moses' pawns he uses.
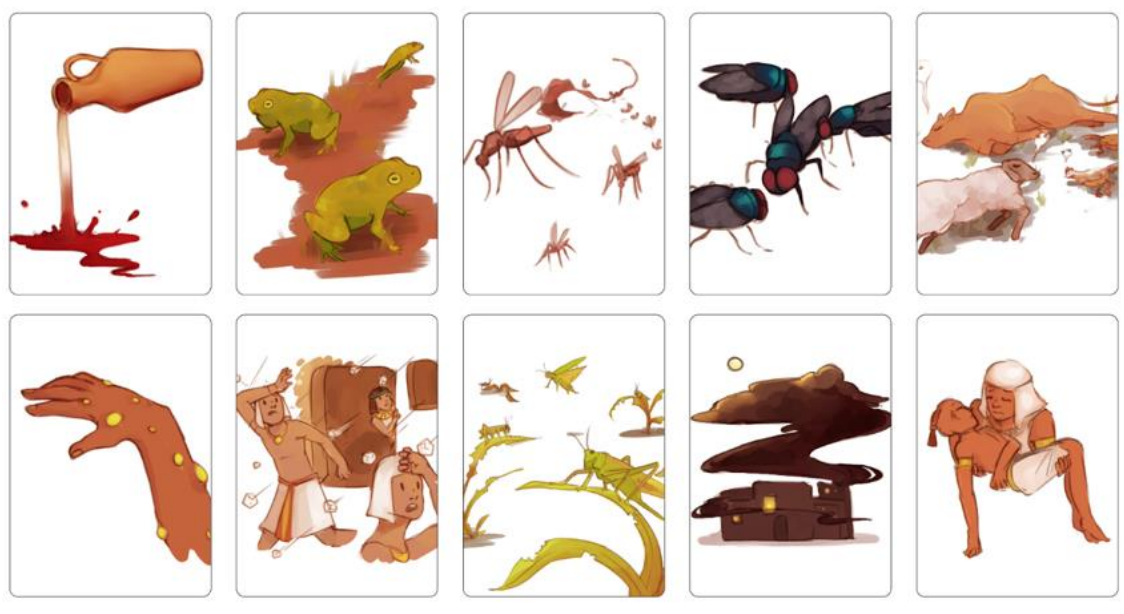

Figure 4. Plague cards

The Calling of Moses has some rules: 1) Each player starts at the starting position $\mathrm{S}$. Then the player will take turns starting the steps by throwing the dice. The number of steps a player can take is based on the face value of the dice obtained at the last roll; 2) If a player occupies a box marked with a Gray Star, then the player has the right to place a color Star card in accordance with the color of his Moses Pawn robe; 3) If the player occupies the box marked (Pharaoh) or (Moses), then the opposing player's turn will open the question card and read it. The player reading the question will also mention the support verse if the question card has a hint (C). If the answering player's answer is correct, then get a reward; 4) A player is said to win if he has reached the tablets of stone box. (Q). 
After the first Game Board prototype is complete, the testing process is carried out. This test was carried out on players with age categories between 20-24, specifically in the Christian student community and the Children Commission of GKI Gejayan Teacher. The purpose of testing at this age is to get a simulation game and also get a more objective evaluation. The evaluation tools used at this testing stage are based on the Game Evaluation Sheet published by Bruce Whitehill (2011). Table 2 shows the results of the evaluation game simulation for two groups.

\begin{tabular}{|c|c|c|c|c|c|}
\hline \multirow{2}{*}{ Game Board Factors } & \multicolumn{3}{|c|}{$\begin{array}{l}\text { What age range do you } \\
\text { think this game is suitable }\end{array}$} & \multirow{2}{*}{ Average } & \multirow{2}{*}{ Meaning } \\
\hline & $9-12$ & $\begin{array}{c}12- \\
\text { adult }\end{array}$ & adult & & \\
\hline Complexity & 5,00 & 5,86 & 7,00 & 5,67 & Rata-rata \\
\hline Game Instructions/Rules & 4,50 & 5,57 & 7,50 & 5,40 & Rata-rata \\
\hline Luck vs. Skill & 5,67 & 6,43 & 6,00 & 6,07 & $\begin{array}{l}\text { half luck, half } \\
\text { skill }\end{array}$ \\
\hline Uniqueness / Game Mechanics & 6,67 & 8,14 & 8,00 & 7,53 & $\begin{array}{l}\text { Almost Very } \\
\text { Different }\end{array}$ \\
\hline Playing time & 5,50 & 6,43 & 8,00 & 6,27 & $\begin{array}{l}\text { Little bit too } \\
\text { long }\end{array}$ \\
\hline Appearance & 8,33 & 7,43 & 8,00 & 7,87 & almost be loved \\
\hline Materials & 9,50 & 8,00 & 8,50 & 8,67 & Above Average \\
\hline Game Idea & 6,67 & 7,57 & 9,00 & 7,40 & Almost Terrific \\
\hline Interest & 8,33 & 7,57 & 9,00 & 8,07 & $\mathrm{OK}$ \\
\hline Repeat Play & 6,33 & 6,57 & 8,00 & 6,67 & now \& then \\
\hline Interaction & 6,17 & 7,43 & 9,00 & 7,13 & $\begin{array}{c}\text { almost all the } \\
\text { time }\end{array}$ \\
\hline Waiting time with nothing to do & 4,00 & 5,43 & 6,00 & 4,93 & Normal \\
\hline Game Options & 5,67 & 4,86 & 7,00 & 5,47 & Just Right \\
\hline Gameboard size & 4,33 & 5,71 & 6,00 & 5,20 & Just Right \\
\hline Game pieces (size) & 4,83 & 5,57 & 5,00 & 5,20 & Just Right \\
\hline Text size & 5,00 & 5,29 & 6,50 & 5,33 & Just Right \\
\hline
\end{tabular}

Table 2. Game Simulation Evaluation Results

The evaluation was carried out on 15 respondents aged 15-39 years with the distribution, as shown in Table 3. The majority of respondents $(70 \%)$ were teachers in the GKI Gejayan Child Commission, and the rest (30\%) were students. 


\begin{tabular}{|c|c|}
\hline Age & Respondent \\
\hline $15-19$ & 2 \\
\hline $20-24$ & 9 \\
\hline $25-29$ & 2 \\
\hline $35-39$ & 2 \\
\hline
\end{tabular}

Table 3. Responden distribution

In general, this board game prototype accepted by respondents as a new tool to assist any player in knowing about Moses. Some respondents give positives feedback in order to make this prototype more attractive and increase interaction between players. One of the feedbacks is to reduce the number of the box in board of game and make more strict rules for player movement. On average, this prototype requires about $40-60$ minutes to make one of the players can reach the finish point.

Game simulations in testing games are carried out in communities that can encourage interest in playing. Figure 5 shows an example of evaluating a game simulation.

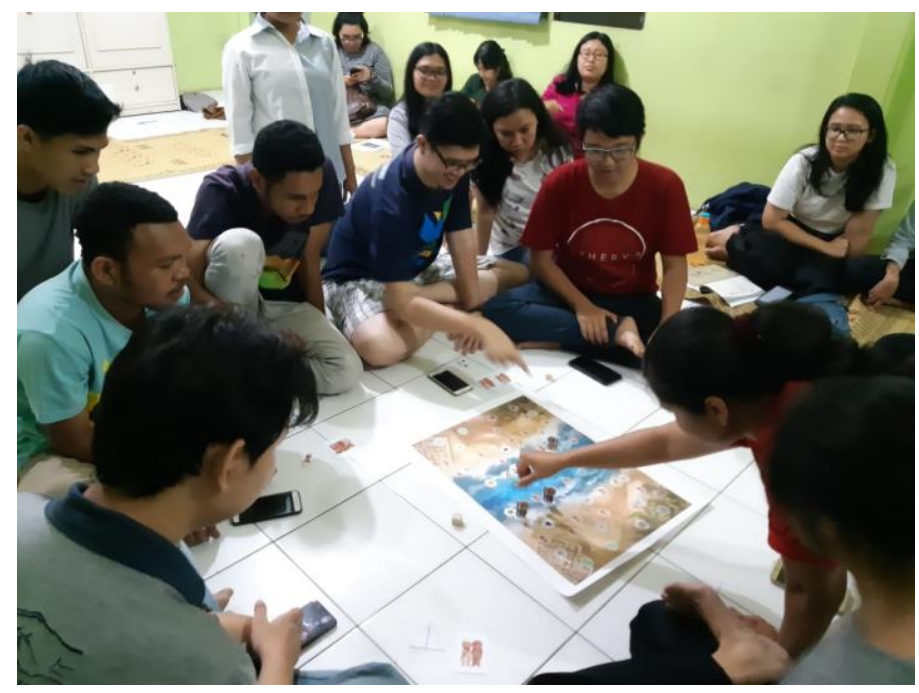

Figure 5. Condition when testing was conducted

From the results of the FGD with the respondents, the play time was needed too long for children. To overcome this, we can cut the map on the game box so that the completed steps are shorter. Another thing that is also a concern of the test results provided can be added so that the questions asked are not too fast. This condition occurs compilation of games played by four players.

Another evaluation result is that if the game is run without a moderator, the game will require more time because each player does not know the answers to most questions. What happens is that the players open the Bible for each question, and that takes longer. Based on these conditions, a valuable input is that in this 
game, a moderator is needed to master the game.

\section{CONCLUSION}

The Calling of Moses can be approved as a new board game to help children or anyone to know Moses. This quality of this board game still needs improvement, especially in the interaction between players and to reduce playing time.

In the future, this board game will be accompanied by a mobile application. The Calling of Moses mobile application is targeted to provide more questions dynamically, more interaction between players, and also give learning materials based on Augmented Reality.

\section{ACKNOWLEDGMENT}

Special thanks to LPPM UKPMW for funding the development of the Calling Musa board game in 2019. To the Children Commission of GKI Gejayan Yogyakarta, thank you very much for taking part in testing and giving a positive evaluation.

\section{BIODATA}

Budi Susanto is a associate professor of Informatics Department on Universitas Kristen Duta Wacana (UKDW), Yogyakarta, Indonesia. He has researches interest in software engineering, semantic web, digital bible service, machine learning.

Wahju Satria Wibowo is assistant professor of Theology, Fac. of Theology Universitas Kristen Duta Wacana, Yogyakarta. He teaches constructive theology and philosophy. His main research is on innovative theology.

Centaury Harjani is a assistant professor of product design Dept on Architecture and Design Faculty from Duta Wacana Christian University, Yogyakarta, Indonesia. She has researches interest in design, fashion, toys, and kids.

Koniherawati is a assistant professor of Product Design Department, Architect and Design Faculty, in Duta Wacana Christian University, Yogyakarta. And a student of Doctoral Program at Sanata Dharma University, Yogyakarta and actives participant in art exhibitions (ceramics, painting and art installation). Her main research on traditional pottery (ceramics), crafts and culture. 


\section{REFERENCES}

Barbosa, A., Pereira, P., Dias, J., \& Silva, F. (2014). A New Methodology of Design and Development of Serious Games. International Journal of Computer Games Technology.

Cherry, K. (2018, Oktober 15). The 4 Stages of Cognitive Development. Retrieved Februari 2, 2019, from verywellmind: https://www.verywellmind.com/piagets-stages-of-cognitive-development2795457

Cherry, K. (2018, Oktober 15). The Concrete Operational Stage of Cognitive Development. Retrieved Februari 2, 2019, from verywellmind.com: https://www.verywellmind.com/concrete-operational-stage-of-cognitivedevelopment-2795458

Freeman, W. (2012, Desember 9). Why board games are making a comeback. Retrieved Februari 2, 2019, from The Guardian: https://www.theguardian.com/lifeandstyle/2012/dec/09/board-gamescomeback-freeman

Harris, C. (2009). Meet the New School Board: Board Games Are Back--And They're Exactly What Your Curriculum Needs. School Library Journal, 55(5), 24-26.

Heaton, T. (2006, Februari 23). A Circular Model of Gameplay. Retrieved Februari 2, 2019, from Gamasutra.com: https://www.gamasutra.com/view/feature/130978/a_circular_model_of_ga meplay.php

John, V. S. (n.d.). Best Practices: Five Tips for Better Playtesting. Retrieved Februari 2, 2019, from Gamasutra.com: https://www.gamasutra.com/view/feature/185258/best_practices_five_tips _for_.php?print $=1$

Mader, S., Levieux, G., \& Natkin, S. (2016). A Game Design Method for Therapeutic Games. 2016 8th International Conference on Games and Virtual Worlds for Serious Applications (VS-GAMES) (pp. 1-8). Barcelona, Spain: IEEE.

Metcalfe, T. (2018, Desember 10). 16 of the Most Interesting Ancient Board and Dice Games. Retrieved Februari 2, 2019, from Live Science: https://www.livescience.com/64266-ancient-board-games.html

More, K. (2018, November 17). A 4,000-Year-Old Bronze Age Game Called 58 Holes Has Been Discovered In Azerbaijan Rock Shelter. Retrieved Februari 2, 2019, from INQUISITR: https://www.inquisitr.com/5167190/a-4000year-old-bronze-age-game-called-58-holes-has-been-discovered-inazerbaijan-rock-shelter/

Siegler, R. S., \& Ramani, G. B. (2009). Playing Linear Number Board GamesBut Not Circular Ones-Improves Low-Income Preschoolers' Numerical Understanding. Journal of Educational Psychology, 101(3), 545-560.

Richard, R. (2005). Game design: theory \& practice. Plano, Texas: Wordware Publishing, Inc. 
Silverman, D. (2013, November 29). How to Learn Board Game Design and Development. Retrieved Februari 2, 2019, from envantotuts+: https://gamedevelopment.tutsplus.com/articles/how-to-learn-board-gamedesign-and-development--gamedev-11607

Steve Jackson Games. (n.d.). Playtesting for Steve Jackson Games. Retrieved Februari 2, 2019, from Steve Jackson Games: http://www.sjgames.com/pyramid/playtest.html

testbytes.net. (2017, Juli 6). 9 Different Types of Game Testing Techniques. Retrieved Februari 2, 2019, from testbytes.net: https://www.testbytes.net/blog/types-of-game-testing/

Walker, D. G. (2014). A Book of Historic Board Games. lulu.com.

Whitehill, B. (2011, 02 02). Game Evaluation Sheet. Retrieved from The Big Game Hunter: https://thebiggamehunter.com/game-evaluation-sheet/ 